\title{
Politizace institutu ústavní odpovědnosti jako jedna z příčin současné ústavní krize v Polsku*
}

\section{Transformation of Constitutional Accountability into Political Weapon as One of the Causes of the Current Constitutional Crisis in Poland?}

\author{
Maxim Tomoszek $^{* *}$
}

\begin{abstract}
Abstrakt
Odborný diskurz se prĭ analýze prícin soúăasné ústavni krize v Polsku zamèruje na problematiku jmenováni soudcu Ústavníbo tribunálu. Tyto problémy jsou však bud'jen beaprostredni prícinou, nebo dokonce spišse

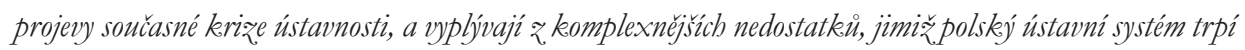
již delši dobu. Jednim z nich je zmèna v chápáni institut ústavni odpovèdnosti a z. toho plynoucí oslabeni respektu ústavnich činitelu k ústavnosti a principum demokratického práuního státu. Cílem prédkládaného textu je tuto základni teqi podrobnèji vymezit a argumentačně a analyticky podporìt. Nejprve uvedu pro českého čtenáre potrébný kontext vymezením základních prvkü polskébo modelu ústavni odpovédnosti a jejich srovnánim s českou úpravou, poté podrobně analyzuji parlamentni fázi řrzeni o ústavni odpovédnosti proti Zbigniewn Ziobrovi a jeji dùsledky pro aktuálni uistavni vývoj, zejména s cílem żdokumentovat politizaci procesu vyvození ústavni odpovédnosti.
\end{abstract}

\section{Klíčová slova}

Polská ústava; ústavni odpovèdnost; Zbigniew Ziobro; ústavni delikt; Státni tribunál; Komise ústavní odpovédnosti Sejmu.

\begin{abstract}
Scholarly discussion analyzing the causes of the current constitutional crisis in Poland focuses on the issue of appointment of judges of the Constitutional Tribunal. These problems, however, are either the direct cause or even only symptoms of the current crisis, resulting from more complex deficiencies, which afflicted the Polish constitutional system for some time. One of them is the change in the understanding of the constitutional accountability and the consequent weakening of respect of constitutional officials for principles of constitutionalism, democracy and rule of law. The aim of this paper is to properly define this thesis, critically analyse it and support with arguments. First, I will provide the necessary context for a Czech reader by defining the basic elements of the Polish model of constitutional accountability and compare it with $C$ zech regulation, then I will analyze in detail the parliamentary phase of constitutional accountability proceedings against Zbigniew Ziobro and their implications for the current constitutional development, in particular in order to document the politicization of the process of applying the constitutional accountability.
\end{abstract}

* Tento článek vznikl v rámci řešení projektu Grantové Agentury ČR „Hledání funkčního modelu ústavní odpovědnosti pro Českou republiku - srovnávací studie“, reg. č. projektu 14-27483P.

** JUDr. Maxim Tomoszek, Ph.D., Katedra ústavního práva, Právnická fakulta Univerzity Palackého v Olomouci / Department of Constitutional Law, Faculty of Law, Palacký University, Olomouc, Czech Republic / E-mail: maxim.tomoszek@upol.cz 


\section{Keywords}

Polish Constitution; Constitutional Accountability; Zbigniew Ziobro; Constitutional Delict; State Tribunal; Commission of Sejm for Constitutional Accountability.

\section{Úvod}

Situace v Polsku se dnes čím dál častěji označuje jako ústavní krize, a nutno podotknout, že právem. Jak jinak označit situaci, kdy vrcholní představitelé státu nerespektují základní zásady demokratického právního státu a Ústavní tribunál nemůže řádně vykonávat své funkce. Odborný diskurz se při analýze př́čin současné situace zaměřil na postavení Ústavního tribunálu, jmenování soudců a související problémy. Domnívám se však, že byt' tyto problémy jsou možná bud' bezprostřední př́činou, nebo dokonce spíše projevy, současné krize ústavnosti, i ony vyplývají z komplexnějších nedostatkủ, jimiž polský ústavní systém dlouhodobě trpí. Jedním z faktorů, které spoluvytvářely podmínky pro vznik současné situace, je změna v chápání ústavní odpovědnosti a z toho plynoucí oslabení respektu ústavních činitelů $\mathrm{k}$ ústavnosti a principům demokratického právního státu. Cílem předkládaného textu je tuto základní tezi podrobněji vymezit a argumentačně a analyticky podpořit. Nejprve uvedu pro českého čtenáře potřebný kontext vymezením základních prvků polského modelu ústavní odpovědnosti a jejich srovnáním s českou úpravou, poté podrobně analyzuji parlamentní fázi rízení o ústavní odpovědnosti proti Zbigniewu Ziobrovi a její důsledky pro aktuální ústavní vývoj, zejména s cílem zdokumentovat politizaci procesu vyvození ústavní odpovědnosti, a to zejména $\mathrm{v}$ jeho parlamentní fázi. Tato fáze je však z hlediska politické praxe nejvýznamnější, nebot' v drtivé většině kauz, včetně př́padu Zbigniewa Ziobra, ř́zení nedospělo do fáze před Státním tribunálem.

\section{Základní prvky polského modelu ústavní odpovědnosti}

V polské právní teorii se ústavní odpovědností rozumí právní odpovědnost osob zastávajících nejvyšší funkce ve státě za jednání související s výkonem této funkce. ${ }^{1}$ Polskou úpravu ústavní odpovědnosti je třeba zařadit do kontinentálního pojetí, které se vyznačuje tím, že o vyvození odpovědnosti rozhoduje vrcholný soudní orgán a zpravidla se týká hlavy státu. ${ }^{2}$ Polský ústavní systém se z tohoto pravidla vymyká širokým vymezením subjektů odpovědnosti a ústavního deliktu, a také funkční procesní stránkou, což umožňuje poměrně časté používání tohoto institutu v praxi.

1 GROMEK, Z. Odpowiedzialność konstytucyjna w Polsce - zarys instytucji. In: ŠíNOVÁ, R. (ed.). Olomoucké práunické dny 2008. 1. část. Olomouc: Iuridicum Olomoucense, 2008, s. 153.

2 GRANAT, M. Normatywny model odpowiedzialności konstytucyjnej w praktyce. In: SKRZYDLO, W. (ed.). Sady i trybunaly w Konstytucji i praktyce. Warszawa: Wydawnictwo Sejmowe, 2005, s. 137-138. 
Institut ústavní odpovědnosti je definován několika klíčovými prvky, které budou postupně stručně představeny: ${ }^{3}$

- kdo odpovídá (subjekt odpovědnosti)

- za co (delikt, včetně zavinění)

- před kým (organizační složka odpovědnosti)

- jakým postupem (procesní složka odpovědnosti)

- s jakými důsledky (sankce).

Ústavní odpovědnost v Polsku dopadá na poměrně široký okruh nejvyšších ústavních činitelů vymezený v čl. 198 odst. 1 a 2 Ústavy RP. ${ }^{4}$ Pro lepší přehlednost je lze rozdělit do čtyř skupin podle typů jednání, za které nesou odpovědnost: ${ }^{5}$

1. prezident, který odpovídá za ústavní delikt a všechny trestné činy,

2. premiér a členové vlády, kteří odpovídají za ústavní delikt a za trestné činy spáchané v souvislosti s výkonem funkce,

3. prezident Národní Banky Polska, prezident Nejvyšší kontrolní komory, členové Státní rady rozhlasového a televizního vysílání, osoby, jež premiér pověríl řízením ministerstva, vrchní velitel ozbrojených sil, kteří odpovídají jen za ústavní delikt,

4. poslanci a senátoři, kteří odpovídají za specifický typ ústavního deliktu. ${ }^{6}$

Ústavní delikt je v čl. 198 odst. 1 Ústavy RP vymezen dvěma prvky - (1) jde o porušení Ústavy RP nebo zákona, (2) kterého se daný funkcionář dopustil v souvislosti s vykonávanou funkcí nebo při výkonu úřední činnosti. Podle čl. 3 Zákona o státním tribunálu ${ }^{7}$ se mohou subjekty dopustit ústavního deliktu i z nedbalosti. Ve vztahu k ústavnímu deliktu je nutno zdůraznit, že se jím rozumí pouze takové jednání, které není trestným činem. Nicméně u prezidenta a členů vlády mohou být i trestné činy předmětem řízení

3 Srov. FILIP, J. K ústavní odpovědnosti v ČR a odpovědnosti hlavy státu zejména za velezradu. Časopis pro právni védu a praxi, roč. 2010, č. 1, s. 24 (21-39); a TOMOSZEK, M. Ústavni odpovédnost v ústavnim systému Polské republiky. Praha: Linde, 2013, s. 50; podobně ve vztahu k odpovědnosti veřejné moci též JIRÁSEK, J. Odpovědnost veřejné moci. In: KLÍMA, K. et al. Státovéda. 2. rozšířené vyd. Plzeň: Aleš Čeněk, 2011, s. 277.

4 Ústava Polské republiky (Konstytucja Rzeczypospolitej Polskiej z dnia 2 kwietnia 1997 r., Dz.U. 97.78.483), ve znění pozdějších předpisů, dále jen Ústava RP.

5 NALEZIŃSKI, B. Organy władzy sądowniczej. In: SARNECKI, P. (ed.). Prawo konstytucyjne RP. 5. vyd. Warszawa: C. H. Beck, 2005, s. 383; DZIAŁOCHA, K. a T. ZALASIŃSKI. Komentáŕ k čl. 198. In: GARLICKI, L. (ed.). Konstytucja Rzecsypospolitej Polskiej. Komentaræ. Tom V. Warszawa: Wydawnictwo Sejmowe, 2007, s. 13-14. Odlišně člení subjekty např. do tří skupin GARLICKI, L. Polskie prawo konstytucyjne. Zarys wykładu. 11. vyd. Warszawa: Liber, 2007, s. 376-377; nebo naopak do pěti SOBCZAK, J. Zakres odpowiedzialności konstytucyjnej. In: SKRZYDLO, W. (ed.). Polskie prawo konstytucyjne. 3. vyd. Lublin: Verba, 2005, s. 413.

6 Konkrétně se jedná o střet zájmů vymezený v čl. 107 Ústavy RP, tedy nabývání majetku z veřejných zdrojů nebo plnění veřejných zakázek.

7 Zákon o Státním tribunálu (Ustawa z dnia 26 marca 1982 o Trybunałe Stanu, Dz.U. 82.11.84), ve znění pozdějších předpisů; poslední novelizace zákonem č. 437 z roku 2016; dále jen Zákon o Státním tribunálu. 
před Státním tribunálem, jedná se tak o specifický případ imunity. V těchto případech plní Státní tribunál funkci trestního soudu a ukládá tresty stanovené v trestním zákoně. Proces vyvození ústavní odpovědnosti lze rozdělit do dvou základních částí - parlamentní a soudní. Parlamentní část zahrnuje postup směřující k podání návrhu na zahájení řízení před Státním tribunálem a ovládají ji zásady typické pro parlamentní právo procesní, zatímco soudní fáze se pak odehrává již před samotným Státním tribunálem s použitím standardů typických pro soudní řízení, jako je např. dvouinstančnost řízení. ${ }^{9}$ Celý postup lze rozčlenit např. takto $^{10}$ :

1. podání návrhu na zahájení řízení o ústavní odpovědnosti,

2. řízení před Komisí ústavní odpovědnosti Sejmu,

3. rozhodnutí o zahájení řízení před Státním tribunálem,

4. prvoinstanční řízení před Státním tribunálem,

5. druhoinstanční řízení před Státním tribunálem,

6. vykonávací řízení.

Návrh na zahájení řízení může podle čl. 6 Zákona o státním tribunálu podat prezident, vyšetřovací komise nebo $1 / 4$ poslanců, resp. 1/4 poslanců a senátorů (pokud se jedná o prezidenta), případně vůči poslancům a senátorům maršálek Sejmu nebo Senátu, a musí splňovat náležitosti stanovené pro obžalobu dle Kodexu trestního řízení. ${ }^{11}$ Podaný návrh se postupuje Komisi ústavní odpovědnosti Sejmu, jejímž úkolem je zjistit, zda ke spáchání daného skutku došlo, zda je ústavním deliktem nebo trestným činem a shromáždit důkazní materiál. Výsledkem práce Komise je zpráva o výsledcích její činnosti spojená s návrhem, zda řízení zastavit nebo podat obžalobu ke Státnímu tribunálu. ${ }^{12}$

K zahájení soudní fáze řízení o ústavní odpovědnosti je třeba usnesení Národního shromáždění ( $v$ případě prezidenta) nebo Sejmu (v ostatních případech) přijatého kvalifikovanou většinou (u prezidenta $2 / 3$, u členů vlády 3/5) nebo absolutní většinou (u ostatních subjektů). ${ }^{13}$ Rízení před Státním tribunálem je procesně velmi podobné řízení

8 PROKOP, K. Trybunał Stanu. In: GRZYBOWSKI, M. (ed.). Prawo konstytucyjne. 2. vyd. Białystok: Temida 2, 2009, s. 353.

9 WINCZOREK, P. Komentarz do Konstytucji Rzeczypospolitej Polskiej z dnia 2 kwietnia 1997 r. Warszawa: Liber, 2000, s. 258.

10 Odlišně viz GARLICKI, L. Polskie prawo..., op. cit., s. 380; GRAJEWSKI, J. Warunki ustawowe i wymogi formalne wstępnego wniosku o pociągnięcie do odpowiedzialności konstytucyjnej przed Trybunałem Stanu. Præeglad Sejmowy, roč. 2003, č. 1, s. 15-16; WILIŃSKI, P. Wszczęcie postępowania w przedmiocie odpowiedzialności konstytucyjnej członka organu kolegialnego. In: KRÓLIKOWSKI, M. a W. ODROWAZŻ-SYPNIEWSKI. Postępowanie pržed Komisja Odpowiedzialności Konstytucyjnej. Zagadnienia systemowe. Warszawa: BAS, 2007, s. 85-86, GROMEK, op. cit., s. 160.

11 Kodex trestního řízení (Ustawa z dnia 6 czerwca 1997, Kodeks postępowania karnego, Dz.U. 97.89.555), ve znění pozdějších předpisů.

12 Podrobněji viz KRÓLIKOWSKI, ODROWĄŻ-SYPNIEWSKI, op. cit., s. 163-172.

13 NALEZIŃSKI, op. cit., s. 390. 
trestnímu. Státní tribunál rozhoduje v první instanci v pětičlenném senátu a ve druhé instanci v sedmičlenném senátu. Soudci se určují losem a jsou vyloučeni soudci, kteří věc již projednávali. ${ }^{14}$

Z pohledu institucionálního je tedy nutné vymezit dva orgány, které mají v rúzení klíčovou úlohu - Komisi ústavní odpovědnosti Sejmu a Státní tribunál. Komise ústavní odpovědnosti Sejmu je dle čl. 18 Jednacího řádu Sejmu ${ }^{15}$ stálou komisí Sejmu, vztahuje se na ni tedy úprava obsažená v čl. 127-129 a dále v čl. 149 a následujících Jednacího řádu Sejmu a dále úprava obsažená v čl. 6 až 13 Zákona o Státním tribunálu. Skládá se z předsedy a místopředsedů, kteří dohromady tvoří předsednictvo, a z dalších členů, jejichž počet není pevně stanoven. Konkrétní složení komise je stanoveno usnesením Sejmu.

Podle článku 199 odst. 1 Ústavy RP se Státní tribunál skládá z předsedy, dvou místopředsedů a 16 členů. Předsedou se virilně stává předseda Nejvyššího soudu, ostatní členové jsou voleni Sejmem na jeho prvním zasedání na dobu jeho funkčního obdobíi. ${ }^{16}$ Oba místopředsedové a polovina členů Státního tribunálu musí podle čl. 199 odst. 1 Ústavy RP dále splňovat podmínky požadované pro výkon funkce soudce. ${ }^{17}$ Ostatní členové Státního tribunálu musejí splňovat alespoň podmínky stanovené v čl. 15 ZST (občanství, bezúhonnost a absence funkce ve státní správě). Základním požadavkem na soudce Státního tribunálu stanoveným v čl. 199 odst. 1 větě první Ústavy RP je, že mají být voleni z osob mimo poslanců a senátorů. Tím je zajišsěna relativní nezávislost Státního tribunálu na moci zákonodárné. Nezávislost Státního tribunálu je ovšem oslabena řadou jiných faktorů: způsobem volby, která se děje podle politického klíče, svázáním funkčního období s volebním obdobím Sejmu, možností znovuzvolení1 ${ }^{18}$ a dále částečně laickým charakterem tribunálu, krátkým funkčním obdobím a absencí materiálního zabezpečení soudců. ${ }^{19}$ Sankce, které může Státní tribunál za spáchání ústavního deliktu uložit, svou povahou odpovídají charakteru ústavní odpovědnosti. Jedná se tedy v prvé řadě o sankce politické, které vyjadřují ztrátu důvěry $\mathrm{k}$ dané osobě, a cílem sankcí je zabránit této osobě v pokračování či v opětovném výkonu veřejné moci a takto zamezit jejímu případnému

14 Čl. 19 Zákona o Státním tribunálu.

15 Usnesení Sejmu Polské republiky ze dne 30. července 1992, Regulamin Sejmu Rzeczypospolitej Polskiej, Monitor Polski 2017, poz. 262, ve znění pozdějších změn.

16 PROKOP, op. cit., s. 351.

17 Podle čl. 61 odst. 1 zákona ze dne 27. července 2001 o organizaci obecných soudo̊ (Dz.U. 01.98.1070 ve znění pozdějších předpisů) jsou těmito požadavky polské státní občanství, plný rozsah civilních a občanských práv, bezúhonnost, ukončené vysokoškolské právní vzdělání s titulem magistr, zdravotní způsobilost, věk alespoň 29 let, složení soudcovské nebo prokurátorské zkoušky a splnění povinné praxe. Poslední dvě podmínky se nezkoumají u notářu a advokátů.

18 ZUBIK, M. Trybunał Stanu - stan Trybunału. In: SZMYT, A. (ed.). Trzecia władza. Sady i trybunały w Polsce. Gdańsk: Wydawnictwo Uniwersytetu Gdańskiego, 2008, s. 50.

19 DZIALOCHA, K. a T. ZALASIŃSKI. Komentář k čl. 199. In: GARLICKI, L. (ed.). Konstytucja Rz̨eczypospolitej Polskiej. Komentarz. Tom V. Warszawa: Wydawnictwo Sejmowe, 2007, s. 6. 
opětovnému zneužití. Podle čl. 25 ZST může Státní tribunál v případě, že shledá obžalovaný subjekt vinným ze spáchání ústavního deliktu, uložit následující sankce:

a) zbavení aktivního a pasivního volebního práva na úřad prezidenta, do Sejmu, Senátu, Evropského parlamentu a do orgánů územních samosprávných celků,

b) zákaz zastávání řídících funkcí nebo plnění úkolů spojených se zvláštní odpovědností ve státních orgánech nebo veřejných organizacích,

c) ztrátu všech nebo některých vyznamenání, hodností a čestných titulů,

d) zbavení poslaneckého nebo senátorského mandátu,

e) zbavení funkce, z jejíhož titulu nese daná osoba ústavní odpovědnost,

f) vưči bývalému prezidentovi je možné vynést dodatkový trest spočívající ve ztrátě nároku na zabezpečení poskytované na základě zákona o zabezpečení bývalého prezidenta Polské republiky. ${ }^{20}$

Tresty spočívající ve ztrátě práv nebo v zákazu některých činností se ukládají na 2 roky až 10 let. Státní tribunál však může ve výjimečných případech pouze konstatovat vinu obžalovaného a trest neukládat. Pokud Státní tribunál rozhoduje o trestných činech, ukládá za ně tresty definované trestním zákonem.

Při srovnání s českou úpravou ústavní odpovědnosti lze největší odlišnosti spatřovat v podstatně širším vymezení subjektů odpovědnosti a ústavního deliktu a v propracovanější procesní úpravě, která zahrnuje fázi vyšetřování v parlamentní komisi. V tomto směru je polské řešení bližší úpravě impeachmentu v USA než českému pojetí. Okruh sankcí je rovněž o něco širší než v ČR a umožňuje Státnímu tribunálu více individualizovat výsledek řízení s ohledem na specifika jednání, kterým došlo ke spáchání ústavního deliktu. Z pohledu potřebných většin je česká a polská úprava podobná.

Obecně lze polskou právní úpravu ústavní odpovědnosti hodnotit kladně s výjimkou konstrukce Státního tribunálu. Na jedné straně je asi vhodné institucionálně oddělit pravomoci v oblasti odpovědnosti ústavních činitelů od soudního přezkumu ústavnosti, aby se tím nezatěžoval výběr soudců ústavního soudu, důsledkem však je svěření rozhodování o ústavní odpovědnosti kvazisoudnímu orgánu s nízkou mírou nezávislosti a velkou hrozbou politického rozhodování.

Poměrně pozitivně bylo možné hodnotit i dosavadní praxi uplatnění ústavní odpovědnosti v Polsku. Zejména na počátku 90. let posloužil institut ústavní odpovědnosti jako velmi efektivní nástroj vyrovnání se s minulostí, nebot’ umožnil vyšetření nezákonností, kterých se dopustili představitelé dřívějš́̌́ho režimu před rokem 1989. Po roce 2000 však postupně docházelo ke snížení četnosti uplatnění ústavní odpovědnosti a také chyběla politická vưle $\mathrm{k}$ dokončení započatých řízení, která tak v drtivé většině ke Státnímu tribunálu nedoputovala. ${ }^{21}$ Postupně také docházelo k politizaci tohoto institutu. Velmi

20 Zákon ze dne 30. května 1996 o zabezpečení bývalého prezidenta Polské republiky (Dz.U. 96.75.356), ve znění pozdějších předpisů.

21 Podrobněji viz TOMOSZEK, M. Praktické uplatnění ústavní odpovědnosti v Polsku. In: JIRÁSEK, J. (ed.). Ústava ve stínu politiky? Olomouc: Iuridicum Olomoucense, 2012, s. 365-380. 
ilustrativní je v tomto směru řizení o ústavní odpovědnosti proti Zbigniewu Ziobrovi. $\mathrm{V}$ dalši části textu na něm budou demonstrovány negativní trendy spojené s ústavní odpovědností a jejich důsledky pro aktuální ústavní situaci.

\section{Politický kontext řízení o ústavní odpovědnosti proti Zbigniewu Ziobrovi}

Kauza Zbigniewa Ziobra má svůj původ v období let 2005-2007, tedy prvního vládního období strany Právo a spravedlnost. Zpočátku vládla strana sama v menšinové vládě, později uzavřela koaliční dohodu se stranami Samoobrona Rzeczypospolitej Polskiej Andrzeje Leppera a Liga Polskich rodzin Macieje Giertycha. Premiérem byl nejprve Kazimierz Marcinkiewicz a po něm od 14. 7. 2006 Jarosław Kaczyński, ministrem spravedlnosti (a zároveň generálním prokurátorem ${ }^{22}$ ) pak právě Zbigniew Ziobro. Zbigniew Ziobro, právník z Krakova, v roce 2001 spoluzakládal stranu Právo a spravedlnost. V témže roce se za tuto stranu stal poslancem Sejmu a v letech 2009-2014 poslancem Evropského parlamentu. V listopadu 2011 byl v důsledku různých afér a skandálů ze strany Právo a spravedlnost vyloučen, proto o měsíc později založil vlastní politické uskupení Solidarna Polska. Přesto se ve volbách v roce 2015 dostal na kandidátku strany Právo a spravedlnost, byl zvolen poslancem Sejmu a od 16. listopadu 2015 je opět ministrem spravedlnosti ve vládě premiérky Beaty Szydło. ${ }^{23}$

Období let 2005-2007 bylo charakteristické mnoha politickými střety mezi vládní stranou Právo a spravedlnost a opoziční Občanskou platformou, které vyústily do předčasných voleb na podzim 2007. Jedním z důležitých faktorů bylo ze zákona vyplývající personální propojení funkce ministra spravedlnosti s funkcí generálního prokurátora, které umožňovalo ministrovi spravedlnosti politickou manipulaci trestních kauz. ${ }^{24}$ Toto poměrně nestandardní řešení, které na první pohled velmi silně zasahuje do (již tak omezené) nezávislosti prokuratury, pocházelo paradoxně nikoli z doby totality, nýbrž teprve z roku 1990, kde bylo výsledkem složitých politických jednání souvisejících s transformací politického systému. Bylo považováno za jednu z možných variant řešení postavení prokuratury v systému státních orgánů, jehož výhodou bylo zajištění efektivity realizace trestní politiky vlády. ${ }^{25}$

Období let 2005 až 2007 jasně ukázalo problémy tohoto řešení, které přímo vybízí ke zneužití, a zkušenosti z těchto let vedly k reformě prokuratury přijaté v roce 2009. Jedním

22 K propojení funkce generálního prokurátora a ministra spravedlnosti viz dále.

23 Podrobněji viz biografické informace na stránkách polského Ministerstva spravedlnosti. Dostupné z: http://ms.gov.pl/pl/o-ministerstwie/kierownictwo-ministerstwa-sprawiedliwosci/, cit. dne 29. 4. 2017.

24 Tyto manipulace byly podrobně zdokumentovány v pozdějším řízení o ústavní odpovědnosti proti Zbigniewu Ziobrovi, viz dále.

25 SKRZYPIŃSKI, D. Prokuratura w polskim systemie politycznym. Wyzwania i dylematy. e-Politikon, č. 19 (podzim 2016), s. 10-11 (6-24). 
z hlavních prvků bylo oddělení funkcí ministra spravedlnosti a generálního prokurátora, kterého nově jmenoval prezident z kandidátů navržených Národní soudní radou (Krajowa Rada Sądownictwa), s cílem zabránit politizaci prokuratury a jejímu zneužívání v politickém boji. ${ }^{26}$ Tato reforma byla ostře kritizována stranou Právo a spravedlnost, ale v určitých ohledech také odbornou veřejností. ${ }^{27}$ Záhy po vítězství Práva a spravedlnosti ve volbách v roce 2015 tato strana prosadila návrat k původnímu systému ${ }^{28}$ spojený s restrukturalizací prokuratury (a navazující personální obměnou vedoucích prokurátorů) a zakotvením nadř́izenosti generálního prokurátora vưči všem prokurátorům. ${ }^{29}$

Způsob, jakým ministr Ziobro své funkce vykonával, zřetelně ilustrují dvě zásadní aféry, které $\mathrm{v}$ konečném důsledku vedly $\mathrm{k}$ pádu vlády a předčasným volbám v roce 2007 - tzv. gruntová aféra a aféra Barbary Blidy. První zmíněná aféra a role Zbigniewa Ziobra v ní byly ve značném rozsahu předmětem návrhu na vyvození ústavní odpovědnosti, jehož vyšetřováním se v letech 2012-2015 zabývala Komise ústavní odpovědnosti Sejmu (viz dále).

Jádrem gruntové aféry byla možnost za úplatek docílit možnosti vynětí pozemků ze zemědělského půdního fondu, a to jednáním osob v nejvyšších funkcích na polském ministerstvu zemědělství. Centrální protikorupční agentura (Centralne Biuro Antykorupcyjne, dále jen CBA) provedla k rozkrytí těchto aktivit provokaci schválenou samotným ministrem Ziobrem, v jejímž rámci mělo dojít k poskytnutí úplatku př́mo ministrovi zemědělství, vicepremiérovi a předsedovi strany Samoobrona Andrzeji Lepperovi. Krátce před tím, než byli aktéři kauzy zatčeni, však došlo k úniku informaci z vyšetřování (podle Leppera přímo od ministra Ziobra), díky němuž Andrzej Lepper z transakce vycouval. ${ }^{30}$ Zjištěné okolnosti však přesto vedly premiéra Jarosława Kaczyńského k odvolání Leppera dne 9. července 2007. Funkcionáři CBA zapojení do organizace provokace byli v roce 2015 odsouzeni za zneužití svých pravomoci, nebot' podle soudu jednali na politickou objednávku, ovšem prezident Duda je 16. listopadu 2015 omilostnil. Tentýž den také jmenoval vládu premiérky Beaty Szydło, v níž jeden z odsouzených, bývalý ředitel CBA Mariusz Kamiński, zastává funkci ministra - koordinátora speciálních služeb. ${ }^{31}$ Andrzej

26 MAZOWIECKA, L. Prokuratura w Polsce 1918-2014. Warszawa: Wolters Kluwer, 2015, s. 161-162.

27 Srov. např. MIK, B. Nowe gwarancje niezależności prokuratury i prokuratorów - fakt czy iluzja. Prokuratura i Prawo, č. 5, roč. 2010, s. 102-116 a další.

28 Zákon ze dne 28. ledna 2016, Prawo o prokuraturze (Dz. U. 2016, poz. 177).

29 SKRZYPIŃSKI, D. Prokuratura w polskim systemie politycznym. Wyzwania i dylematy. e-Politikon, č. 19 (podzim 2016), s. 13-14 (6-24).

30 BUTKIEWICZ, T. Leppera uratował przeciek. Driennik.pl, 13. 10. 2007. Dostupné z: http://wiadomosci.dziennik.pl/polityka/artykuly/217434,leppera-uratowal-przeciek.html, citováno dne 30. 4. 2017.

31 Prezydent ułaskawił m.in. b. szefa CBA Mariusza Kamińskiego. Polska Agencja Prasowa, 17. 11. 2015. Dostupné z: http://www.pap.pl/aktualnosci/news,432779,prezydent-ulaskawil-min-b-szefa-cba-mariusza-kaminskiego.html, citováno dne 30. 4. 2017. 
Lepper byl později obviněn z křivé výpovědi o tom, kdo jej před provokací varoval, ovšem před dokončením procesu spáchal 5. 8. 2011 sebevraždu. ${ }^{32}$

Zbigniew Ziobro hrál zásadní roli také v kauze Barbary Blidy. Tato politička byla v letech 1989-2005 poslankyní Sejmu za Sociální demokracii Polska a později od roku 1999 za Svaz demokratické levice. V letech 1993-1996 byla ministryní územního plánování a stavebnictví. Patřila k nejpopulárnějším politikům ve Slezsku. Zemřela za podezřelých okolností ráno 25. dubna 2007 v době, kdy ji domů přišli zadržet př́slušníci Agentury vnitřní bezpečnosti. Důvodem zadržení byl údajný podíl Barbary Blidy v úplatkářské kauze tzv. uhelné mafie ${ }^{33}$ a dalších souvisejících podezřelých aktivit. Oficiální vyšetřování její smrti bylo uzavřeno s tím, že si střelné zranění Barbara Blida způsobila sama vlastní legálně drženou zbraní a jedná se tedy o sebevraždu. Podle zprávy zvláštní vyšetřovací komise ustavené v této věci Jarosław Kaczyński a Zbigniew Ziobro řídili vyšetřování kauzy uhelné mafie a zadržení Barbary Blidy, přičemž Ziobro měl k tomu od premiéra zvláštní pověření, které bylo vydáno mimo rámec Ústavy, to vše s cílem eliminovat politické oponenty. Zbigniew Ziobro podle komise také o okolnostech kauzy nepravdivě informoval poslance Sejmu. ${ }^{34}$

\section{3 Řízení o ústavní odpovědnosti proti Zbigniewu Ziobrovi}

Př́pad Barbary Blidy se stal synonymem pro mechanismus, jakým Jarosław Kaczyński a Zbigniew Ziobro využívali orgány činné v trestním řízení k boji proti opozičním politikům. Vzhledem k množství zvláštních okolností, které provázely vyšetřování Barbary Blidy, její zadržení i následné vyšetřování její smrti, ${ }^{35}$ byla záhy po její smrti (a po předčasných volbách v roce 2007) ustanovena vyšetřovací komise. Ta po čtyřech letech činnosti došla k závěrům, že Ziobro i Kaczyński se v této kauze dopustili ústavního deliktu a mělo by být vưči nim zahájeno řízení o ústavní odpovědnosti. ${ }^{36} \mathrm{~K}$ tomu skutečně došlo,

32 KĄCKI, M. Prokuratura ustaliła, dlaczego Andrzej Lepper popełnił samobójstwo. Wyborcza.pl, 19. 12. 2012. Dostupné z: http://wyborcza.pl/1,76842,13074777,Prokuratura_ustalila_dlaczego_Andrzej_Lepper_popelnil.html, citováno dne 30. 4. 2017.

33 Mafie měla ve státních dolech organizovat falšování dokumentů prokazujících kvalitu uhlís cílem prodat kvalitní uhlí za nízké ceny firmám, které ho pak přeprodávaly se ziskem dále. Dalšími zdroji přijmu byly machinace s prodejem vybavení dolů, ovlivňování fakturační doby nebo cílené bankroty firem obchodujících s uhlím vedoucí k nemožnosti vymoci dlužné platby za odběr uhlí. Podrobněji viz např. Sąd: Istniała tropiona przez PiS „mafia węglowa“. Dostupné z: http://katowice.wyborcza.pl/katowice/1,35063,19174981,sad-istniala-tropiona-przez-pis-mafia-weglowa.html, citováno dne 29. 11. 2016.

34 KUBLIK, A. a W. CZUCHNOWSKI. Komisja Blidy: Kaczyński i Ziobro przed Trybunał Stanu. Gazeta Wyborcza, 14. 6. 2011, [online]. Citováno dne 28. listopadu 2016. Dostupné z: http://wyborcza. pl/1,75478,9779322,Komisja_Blidy_Kaczynski_i_Ziobro_przed_Trybunal_Stanu.html

35 WIATR, J. J. Refleksje o odpowiedzialności polityków. Res Humana, roč. 2011, č. 4, s. 3.

36 KUBLIK, A. a W. CZUCHNOWSKI. Komisja Blidy: Kaczyński i Ziobro przed Trybunał Stanu. Gazeta Wyborcza, 14. 6. 2011, [online]. Citováno dne 28. listopadu 2016. Dostupné z: http://wyborcza. pl/1,75478,9779322,Komisja_Blidy_Kaczynski_i_Ziobro_przed_Trybunal_Stanu.html 
byt' jen ve vztahu ke Zbigniewu Ziobrowi, když proti němu dne 19. listopadu 2012 podalo 86 poslanců Občanské platformy, 25 poslanců Svazu demokratické levice a 41 poslanců strany Ruch Palikota vstupní návrh na zahájení ř́zení o ústavní odpovědnosti. ${ }^{37}$ V návrhu bylo Zbigniewu Ziobrovi kladeno za vinu, že v době výkonu funkce ministra spravedlnosti:

1. zneužíval své pravomoci s cílem diskreditovat opoziční politiky skrze snahu dokázat jejich napojení na tzv. „spiknutí“, tedy zločinného spolčení politicko-hospodářsko-personálního charakteru; zneužití pravomocí se týkalo zejména účelových trestně-procesních kroků proti údajným členům ,spiknuti““, určovaným zejména podle politických názorů,

2. na základě nezákonného zmocnění od premiéra vyžadoval informace a řídil složky ministerstva vnitra, policie, protikorupčního úřadu a vnitřní bezpečnostní služby,

3. vydal před volbami v roce 2007 okresní prokurátorce ve Varšavě pokyn, aby nevykonávala úkony trestního řízení proti ministrovi sportu ve vládě Jarosława Kaczyńského, Tomaszovi Lipcovi,

4. prováděl v roce 2007 jako generální prokurátor dozor nad trestním řízením ve věci, kde byl sám svědkem, a nevyloučil sebe ani svého podřízeného ve stejné situaci, a směřoval dané ř́zení tak, aby vina padla na politicky vytipovanou osobu, kterou byl tehdejší ministr vnitra Janusz Kaczmarek,

5. s cílem veřejně diskreditovat ministra vnitra Janusze Kaczmarka, Jaromira Netzla, Konrada Kornatowskiého a další osoby, jako dozorující prokurátor vyloučil část jejich trestního spisu k samostatnému přezkoumání jinou prokuraturou a poté rozhodl o jejich obvinění, zadržení a předvedení na okresní prokuraturu ve Varšavě, což následně jeho zástupce, Jerzy Engelking, využil na tiskové konferenci k veřejné prezentaci obvinění proti nim, a to že jsou dané osoby zdrojem vědomých úniků informací z trestního řízení ve věci tzv. gruntové aféry,

6. v roce 2007 nezákonně zbavil dozoru nad trestními řízeními uvedenými v předchozích bodech prokurátorku odvolací prokuratury ve Varšavě Marzenu Kowalskou,

7. v roce 2007 bez existence zákonných důvodů požadoval po policejním prezidentovi a vedoucím ústředního úradu vyšetřování, aby pokračovali v prověřování novináře Wojciecha Czuchnowského,

8. nesplnil svou dozorovou pravomoc v rámci funkce generálního prokurátora a s cílem zajištění politického prospěchu straně Právo a spravedlnosti schválil návrhy vedoucího ústředního protikorupčního úřadu na prověření činnosti místopředsedy vlády Jarosława Kaczyńského Andrzeje Leppera a dalších osob ze strany Sebeobrana (koaliční partner Práva a spravedlnosti), přestože neexistovaly důkazy o tom, že by se dané osoby dopustily skutků, které by zakládaly pravomoc ústředního protikorupčního úřadu.

37 Wstępny wniosek o pociagnięcie do odpowiedzialności konstytucyjnej przed Trybunałem Stanu byłego Ministra Sprawiedliwości i Prokuratora Generalnego Pana Zbigniewa Ziobro. Dostupné z: http:/ /www. sejm.gov.pl/sejm7.nsf/files/MKOK-92HE5U/\$File/wniosek_ts_2.pdf, citováno dne 30.11. 2016. 
Komise ústavní odpovědnosti Sejmu se návrhem zabývala dva roky ve velké míre podrobnosti a provedla rozsáhlé dokazování s množstvím svědeckých výpovědí. ${ }^{38}$ Komise dospěla k závěru, že skutky uvedené v bodech 3 a 7 nebyly prokázány a ve vztahu k nim navrhla ŕízení zastavit. U zbývajících šesti skutků však komise dospěla k závěru, že se skutky staly, že jimi došlo k naplnění ústavního deliktu nebo dokonce skutkové podstaty trestného činu, a doporučila Sejmu, aby podal Státnímu tribunálu návrh na zahájení soudní fáze řízení o ústavní odpovědnosti. ${ }^{39}$ Ze získaných podkladů je velmi zřetelně patrné, jak Zbigniew Ziobro zneužil propojení funkce ministra spravedlnosti s funkcí generálního prokurátora k ovlivňování orgánů činných v trestním řízení s cílem diskreditovat politické oponenty, a jak tomu napomohl premiér Jarosław Kaczyński zrrízením tzv. meziresortních skupin pro boj s organizovaným zločinem a s hospodářskou kriminalitou. ${ }^{40}$

O to více je s podivem, že při hlasování v Sejmu návrh na zahájení rrízení před Státním tribunálem o pouhých pět hlasů neprošel: potřebná 3/5 většina představuje 276 hlasů a pro hlasovalo 271 poslanců. Při hlasování chybělo devět členů Občanské platformy (mj. premiérka Ewa Kopacz a bývalý maršálek Sejmu Radosław Sikorski) a dalších 11 poslanců koaličních stran. ${ }^{41}$ Paradoxem je, že Zbigniew Ziobro je v současnosti opět ministrem spravedlnosti a generálním prokurátorem.

\section{Politizace řízení o ústavní odpovědnosti jako důsledek kauzy Zbigniewa Ziobra}

Pro řízení bylo po celou dobu charakteristické, že členové strany Právo a spravedlnost je chápali jako politickou odvetu nebo mstu ze strany Občanské platformy. Je to dobře patrné ze zápisů z jednání Komise ústavní odpovědnosti Sejmu. Přestože návrh byl podán společně poslanci tří spíše levicových nebo středových politických stran, je z postupu poslanců Práva a spravedlnosti patrná snaha dát ř́izení o ústavní odpovědnosti cejch zpolitizovaného procesu iniciovaného zejména Občanskou platformou. ${ }^{42}$ Vzhledem

38 Celkem se Komise ústavní odpovědnosti Sejmu návrhem zabývala v období od 10. července 2013 do 8. srpna 2015 na 36 zasedáních. Viz zápisy ze zasedání Komise. Dostupné z: http://www.sejm.gov. $\mathrm{pl} / \mathrm{sejm} 7 . \mathrm{nsf} /$ biuletyny.xsp? view =2 \& komisja=ODK \& page=1, citováno dne 29. 11. 2016.

39 Viz Zápis ze zasedání Komise ústavní odpovědnosti Sejmu ze dne 24. června 2015, kde byl projednán koncept zprávy o řízení ve věci ústavní odpovědnosti Zbigniewa Ziobra. Dostupné z: http://www.sejm. gov.pl/sejm7.nsf/biuletyny.xsp?view=2 \& komisja=ODK, citováno dne 22. listopadu 2016.

40 Tamtéž, s. 5, a podrobněji viz Zápis ze zasedání Komise ústavní odpovědnosti Sejmu ze dne 9. července 2014, kde byl vyslýchán bývalý premiér Kazimierz Marcinkiewicz, s. 6 a násl.; Dostupné z: http://www. sejm.gov.pl/sejm7.nsf/biuletyny.xsp?view=2 \& komisja=ODK, citováno dne 22. listopadu 2016.

41 Sejm odrzucił wniosek o Trybunał Stanu dla Zbigniewa Ziobry. Zabrakło pięciu głosów. Dostupné z: http://www.tvp.info/21791851/zbigniew-ziobro-nie-stanie-przed-trybunalem-stanu-zabraklo-czterech-glosow, citováno dne 27. listopadu 2016.

42 Viz nap̌r. vyjádření poslance Práva a spravedlnosti Kazimierza Smolińského na zasedání konaném dne 24. června 2015, kde byl projednán koncept zprávy o řízení ve věci ústavní odpovědnosti Zbigniewa Ziobra. Dostupné z: http://www.sejm.gov.pl/sejm7.nsf/biuletyny.xsp?view=2 \& komisja=ODK, citováno dne 22. listopadu 2016. 
ke zjištěným objektivním skutečnostem, které prokazují ze strany Zbigniewa Ziobra manipulaci postupu orgánů činných v trestním řízení, a to v převážné většině v neprospěch politických oponentů strany Právo a spravedlnost, to byla snaha nepř́liš opodstatněná.

Poměrně zřetelně však poukázala na určitou slabinu v konstrukci systému ústavní odpovědnosti, kterou představuje silný politický prvek v jeho počáteční (parlamentní) fázi. Dobře si ji uvědomoval i premiér Donald Tusk, který prohlásil, že by vládnoucí strana neměla využívat proti lídrům opozice trestní prostředky. ${ }^{43}$ Zvláště v kontextu jednání, která byla Zbigniewu Ziobrovi dávána za vinu v podobě ústavního deliktu, to velmi přesně vystihuje křehkou rovnováhu mezi objektivní spravedlností a politickým soupeřením. Je možné, že právě tato nejistota, zda skutečně postupovat proti politickým oponentům tak tvrdě, byla nakonec prŕíčinou neúspěšného hlasování v Sejmu.

Domnívám se však, že uvedený pohled na systém ústavní odpovědnosti je zkreslený. Pokud se opravdu podrobně podíváme na konstrukci ústavní odpovědnosti, zjistíme, že minimálně její parlamentní fáze je koncipována nikoli jako prostředek nátlaku většiny, ale naopak jako mechanismus ochrany menšin. Vstupní návrh na zahájení řízení totiž může podat pouhá $1 / 4$ poslanců. Ř́zení dále pokračuje před Komisí ústavní odpovědnosti Sejmu, která je sice obsazená stranicky, ale vzhledem k tomu, že v průběhu dokazování se používají principy a postupy charakteristické pro přípravnou fázi trestního řízení, nejedná se ryze politický proces a rozhodování. I pokud by během jednání Komise došlo $\mathrm{k}$ tomu, že by bylo hlasováno po stranických liniích a většina by takto bez podkladu v důkazech přehlasovala menšinu, má menšina právo předložit Sejmu menšinové stanovisko, které v konečném důsledku může v Sejmu získat většinovou podporu a stát se základem pro řízení před Státním tribunálem.

Je rovněž pomíjen význam důkazního řízení před Komisí ústavní odpovědnosti Sejmu pro zjištění skutečných okolností namítaných ústavních deliktů. Jejich následné zveřejnění v zápisech a ve zprávě Komise, i když nemusí vést k zahájení soudní fáze řízení o ústavní odpovědnosti, je nesmírně dưležité pro občany a voliče k získání informací o svých zástupcích a lid může tyto informace zohlednit ve volbách. Dokonce i tlak veřejného mínění vyvolaný zjištěnými skandálními informacemi může vést $\mathrm{k}$ dobrovolnému odstoupení politika či k jeho „obětování“ pro dobro jeho domovské politické strany.

Je také nutné zdůraznit, že celá parlamentní fáze je pouze fáze vstupní, iniciační, protože finální rozhodnutí je pravomocí Státního tribunálu. I kdyby hlasování v Komisi ústavní odpovědnosti, v Sejmu nebo v Národním shromáždění byla motivovaná politicky, standardy řízení před Státním Tribunálem včetně možnosti podat proti jeho rozhodnutí ústavní stížnost dávají dostatečné záruky, že řízení před ním již politickou povahu mít nemůže. Ve srovnání s trestním ř́zením představuje řízení o ústavní odpovědnosti

43 „Skoro są zarzuty, to musi je wyjaśnić Trybunał Stanu”. Minister sprawiedliwości o sprawie Ziobry. Dostupné z: http://www.tvp.info/21783024/skoro-sa-zarzuty-to-musi-je-wyjasnic-trybunal-stanu-minister-sprawiedliwosci-o-sprawie-ziobry, citováno dne 1. prosince 2016. 
daleko menší zásah do základních práv dotčené osoby, at’ již s ohledem na případné sankce nebo na omezení, který z řízení vyplývají (absence vazby apod.). Navíc při neúspěchu řízení před Státním tribunálem může nakonec strana, která ho prosadila, politické body ztratit, a to je také jedním z aspektů, které budou př̀i hlasování v parlamentní fázi řízení určitě zvažovány.

Důsledkem řízení o ústavní odpovědnosti proti Zbigniewu Ziobrovi je tak zkreslení povahy tohoto řízení a jeho přenesení do politické roviny, což je nutné hodnotit jednoznačně negativně. ${ }^{44}$ Je samozřejmé, že v očích veřejnosti to značně degraduje jeho hodnotu jako prostředku hledání spravedlnosti a do budoucna to patrně výrazně sníží jeho reálnou využitelnost. Je přitom zcela nerozhodné, že řízení v Komisi ústavní odpovědnosti Sejmu poskytlo množství důkazů, že Zbigniew Ziobro se většiny skutků dávaných mu za vinu, které naplňovaly skutkovou podstatu ústavního deliktu, skutečně dopustil.

Z pohledu strany Právo a spravedlnost zpolitizování ústavní odpovědnosti nepředstavuje větší problém, protože její představitelé patrně neměli v plánu tohoto institutu reálně využít. Naopak nestandardní výměna šéfů všech čtyř speciálních služeb, která proběhla v noci bezprostředně po vyslovení důvěry vládě Beaty Szydło, ${ }^{45}$ svědčí o tom, že je spíše namístě obava z využívání metod uplatněných již v letech 2005-2007, tedy manipulace orgánů činných v trestním ř́zení a jejich zneužití proti politickým protivníkům. Oproti předchozímu období však je riziko tentokrát významně posíleno tím, že hned koncem roku 2015 a začátkem roku 2016 byla významně oslabena role Ústavního tribunálu, který je dnes prakticky nefunkční.

\section{Závěr}

Obecným problémem, z něhož pramení současná polská ústavní krize, je výrazná polarizace společnosti, která se přenáší i na politickou scénu. Podobný jev můžeme, byt' v méně intenzivní podobě, sledovat i v ČR. ${ }^{46} \mathrm{~V}$ Polsku se jedná o záležitost dlouhodobou, jak ukazuje např. reflexe Lecha Garlického ohledně výběru soudů Ústavního tribunálu v Polsku v letech 1989-2002, kdy v důsledku vůdčí role Sejmu byli soudci v zásadě vybírání vládnoucí stranou. ${ }^{47}$ Navíc se nejedná o jev omezený pouze na jedno politické

44 Srovnej pohled Richarda K. Neumanna na politizaci impeachmentu v USA - viz NEUMANN, R. K. The Revival of Impeachment as a Partisan Political Weapon. Hastings Constitutional Law Quarterly, roč. 34, č. 2 (Winter 2007), s. 162 (161-327).

45 KOŚMIŃSKI, P. Zmiany w służbach specjalnych pod osłoną nocy. PiS tłumaczy: Każda minuta funkcjonowania tych osób; Dostupné z: http://wyborcza.pl/1,75398,19211198,zmiany-w-sluzbach-specjalnych-pod-oslona-nocy-pis-tlumaczy.html, citováno dne 2. 12. 2016.

46 Viz BOČEK, J., J. MAZÁK a M. ZLATKOVSKÝ. Rozdèlená společnost? Čechy proti sobè stavi věk a vždělání. Dostupné na: https://interaktivni.rozhlas.cz/rozdelena-spolecnost/, citováno dne 2. 12. 2016.

47 GARLICKI, L. The Experience of the Polish Constitutional Court. In: SADURSKI, W. (ed.). Constitutional Justice, East and West. Democratic Legitimacy and Constitutional Courts in Post-Communist Europe in a Comparative Perspective. Hague: Kluwer Law International, 2002, s. 268. 
uskupení - naopak, do jisté míry se na vzniku a fungování tohoto systému podílely všechny relevantní politické strany, byt', jak ukazují např. výše citovaná vyjádření Donalda Tuska, Občanská platforma si negativní aspekty tohoto systému patrně uvědomovala a měla snahu to nějak zohlednit.

Při nárůstu politického pnutí může ústavní odpovědnost působit jako mechanismus řešení politických konfliktů díky tomu, že umožňuje vyšetření podezřelých činností a v případě potřeby také odstranění zkorumpovaných politiků. Tuto funkci však mưže plnit pouze v podobě nepolitického nástroje akceptovaného napříč politickým spektrem. Praktické uplatňování ústavní odpovědnosti v Polsku tímto způsobem však probíhalo zejména v 90. letech minulého století, což bylo dáno změnou režimu, množstvím afér, se kterými bylo třeba se vypořádat, ale zejména společnou vưlí většiny politických subjektů ústavní odpovědnost vyvodit. Množství spáchaných deliktů v té době kromě chaotické atmosféry transformace odráželo také nedocenění odpovědnostních mechanismů. Po roce 2000 však postupně došlo k výrazné polarizaci politické scény a v souvislosti $\mathrm{s}$ tím k politizaci mechanismu ústavní odpovědnosti. To se projevilo výrazným poklesem počtu zahájených řízení. Svým zpơsobem lze tedy sledovat přechod od mezistranického vyvození ústavní odpovědnost ke stranickému boji. Nikoli v rovině, kdy by obvinění byla uměle vytvářena s cílem pošpinit konkrétní osoby, ale spíše $\mathrm{v}$ té rovině, že žádná z politických stran nemá zájem strrílet do vlastních řad, což činí získání potřebné většiny v Sejmu téměř nereálným.

Kauza Zbigniewa Ziobra, zejména v důsledku snahy strany Právo a spravedlnost vykreslit toto řízení jako politický proces, jako odvetu Občanské platformy, vedla k výraznému oslabení významu ústavní odpovědnosti a důvěry společnosti v tento mechanismus. Jasně ukázala, že v ústavní praxi nejde jen o právní předpisy a jejich aplikaci. Velmi důležité je politické prostředí, veřejné mínění a důvěra společnosti i politické reprezentace v ústavně vymezené postupy. Oslabením ústavní odpovědnosti ve spojení s paralýzou Ústavního tribunálu došlo k praktickému vyloučení dvou hlavních nástrojů právní odpovědnosti a tím k zásadnímu ohrožení právního státu. Náprava těchto necitlivých zásahů do ústavního systému s cílem upevnit politickou moc nebude jednoduchá, protože jí nelze docílit pouze právními postupy. Znovuvybudování ztracené důvěry společnosti v demokratický právní stát je možné, jedině pokud ve společnosti př́tomný konflikt ztratí na své intenzitě. Jedním z kroků na této cestě musí být všeobecný prríklon k základním ústavním hodnotám bez ohledu na to, zda při dosahování krátkodobých politických cílů jsou někomu k užitku či naopak překážkou. 